\title{
KAJIAN PERENCANAAN PERSEDIAAN YANG OPTIMAL DENGAN METODE EOQ PADA PT. XYZ
}

\author{
Sri Suharti \\ Program Studi Teknik Industri, Universitas Buana Perjuangan Karawang \\ Jl. HS. Ronggowaluyo, Telukjambe Timur, Karawang, 41361
}

\begin{abstract}
ABSTRAK
Penelitian ini bertujuan untuk menentukan besar jumlah atau quantity yang harus di pesan untuk masing-masing material per customer dengan menggunakan metoda $E O Q$, menentukan besar persediaan pengaman (Safety stock) yang ideal yang harus disediakan, menentukan waktu yang tepat untuk melakukan pemesanan kembali (Reorder point) dari masing-masing material per customer, menentukan biaya total persediaan material (TIC) yang harus dikeluarkan oleh PT. XYZ. Data penelitian merupakan data dari bulan Januari 2015 sampai dengan Desember 2015. Data yang diperoleh adalah data primer dan data sekunder. Metode analisis yang digunakan dalam penelitian ini adalah metode $E O Q$. Hasil penelitian menunjukkan bahwa pembelian yang optimal menurut Metode EOQ selama periode tahun 2015 untuk setiap kali pesan lebih besar daripada yang dilakukan perusahaan. Sedangkan total biaya persediaan (TIC) lebih kecil daripada yang dilakukan perusahaan yaitu dapat menghemat sebesar $60.5 \%$. Implementasi metode $E O Q$ dapat direkomendasikan untuk mengetahui kuantitas pemesanan atau pembelian optimal dengan tujuan meminimalkan biaya persediaan yang terdiri dari biaya pemesanan dan biaya penyimpanan.
\end{abstract}

Kata Kunci : Persediaan, Economic Order Quantity, Reorder Point, Safety Stock, Total biaya persediaan, biaya pemesanan, biaya penyimpanan.

\section{PENDAHULUAN}

PT. XYZ merupakan perusahaan stockiest yang menyediakan material Logam non ferrous untuk customer yang berada di wilayah Indonesia dengan cara 100\% import terutama dari Jepang,. Karena perusahaan ini merupakan stockiest material sehingga unsur persediaan (inventory) merupakan hal yang sangat penting untuk perusahaan ini. Pertumbuhan jumlah customer dan demand harus diimbagi oleh persediaan yang optimal sehingga semua permintaan customer terpenuhi, pembayaran ke supplier tetap terjaga (Account Payable) dan cost persediaan optimal. Disamping itu untuk menekan biaya pemesanan sebagai akibat pembelian yang dilakukan berdasarkan forecast dari customer tanpa memperhitungkan besarnya biaya pemesanan.

Dari fenomena yang telah dijelaskan di atas dapat ditarik kesimpulan bahwa permasalahan yang ada di PT. XYZ adalah bagaimana melakukan control material sehingga dapat menyerap terjadinya fluktuasi demand dari customer.

Berdasarkan uraian latar belakang di atas, maka dilakukan penelitian mengenai "Kajian Perencanaan Persediaan Yang Optimal dengan Metode EOQ Pada PT. XYZ". Penelitian ini bertujuan untuk mencoba membantu PT. XYZ dengan mencari akar permasalahan (root couse) yang ada berdasarkan pengumpulan dan pengolahan data.

Dari hasil tersebut diharapkan perusahaan mampu menjalankan operasionalnya dengan perencanaan yang matang, dan dengan biaya yang optimal, sehingga mampu bersaing 
dan memenuhi semua permintaan customer. Dengan demikian bukan saja mampu bertahan bahkan tumbuh menjadi pesat.

Untuk mendukung dan melandasi konsep keilmuan secara ilmiah maka dilakukan pengumpulan teori-teori yang relevan yang berasal dari jurnal hasil penelitian terdahulu dan buku teks sebagai kajian pustaka.

\section{Definisi Persediaan dan Timbulnya Persediaan}

Persediaan merupakan stock yang dibutuhkan perusahaan untuk mengatasi adanya fluktuasi permintaan.

Nasution dan Prasetyawan (2008:115) dan Ginting (2007:122) menjelaskan beberapa alasan

persediaan/timbulnya persediaan yaitu :

1. Mekanisme pemenuhan atas permintaan (transaction motive). Permintaan akan suatu barang tidak akan dapat dipenuhi dengan segera bila barang tersebut tidak tersedia sebelumnya, karena untuk mengadakan barang tersebut diperlukan waktu untuk pembuatannya maupun untuk mendatangkannya.

2. Adanya keinginan untuk meredam ketidakpastian (precautionary motive), seperti :

a. Adanya permintaan yang bervariasi dan tidak pasti dalam jumlah maupun waktu kedatangan.

b. Waktu pembuatan yang cenderung tidak konstan antara satu produk dengan produk yang lain.

c. Waktu ancang-ancang (lead time) yang cenderung tidak pasti karena berbagai faktor yang tak dapat dikendalikan sepenuhnya.

d. Ketidakpastian ini akan diredam oleh jenis persediaan yang disebut persediaan pengaman (safety stock). Persediaan pengaman ini digunakan jika permintaan melebihi peramalan, produksi lebih rendah dari rencana atau waktu ancang-ancang (lead time) lebih panjang dari yang diperkirakan semula.

3. Keinginan melakukan spekulasi (speculative motive) yang bertujuan mendapatkan keuntungan besar dari kenaikan harga barang dimasa mendatang.

\section{Masalah Umum Persediaan}

Masalah umum yang terjadi pada persediaan adalah menimbulkan suatu permasalahan terkait dengan biaya yang ditimbulkan.

Sofyan (2013:117) berpendapat bahwa dua masalah umum yang dihadapi suatu sistem didalam mengelola persediaan :

1. Masalah Kuantitatif : yaitu hal-hal yang berkaitan dengan penentuan kebijakan perusahaan, antara lain :

a. Berapa banyak jumlah barang yang dipesan/dibuat

b. Kapan pemesanan/pembuatan barang harus dilakukan

c. Berapa jumlah persediaan pengamannya

d. Metode pengendalian persediaan mana yang paling tepat

2. Masalah Kualitatif : yaitu hal-hal yang berkaitan dengan sistem pengoperasian persediaan yang akan menjamin kelancaran pengelolaan sistem persediaan, seperti :

a. Jenis barang apa yang dimiliki

b. Dimana barang tersebut berada

c. Berapa jumlah barang yang sedang dipesan 
d. Siapa saja yang menjadi pemasok (supplier) masing-masing item

\section{Jenis-jenis Persediaan}

Menurut Nasution dan Prasetyawan (2008: 113) jenis-jenis persediaan secara umum terbagi 4 macam, yaitu :

1. Bahan baku (raw materials) adalah barang-barang yang dibeli dari pemasok (supplier) dan akan digunakan atau diolah menjadi produk jadi.

2. Bahan setengah jadi (work in process) adalah bahan baku yang sudah diolah atau dirakit menjadi komponen namun masih membutuhkan langkah-langkah lanjutan agar menjadi produk jadi.

3. Barang jadi (finished goods) adalah barang jadi yang telah selesai diproses, siap untuk disimpan digudang barang jadi, dijual atau didistribusikan ke lokasi-lokasi pemasaran.

4. Bahan-bahan pembantu (supplies) adalah-barang-barang yang dibutuhkan untuk menunjang produksi, namun tidak akan menjadi bagian pada produk akhir yang dihasilkan perusahaan.

\section{Komponen-Komponen Dasar Biaya Persediaan}

Sofyan (2013: 52) menggolongkan biaya pada system persediaan ada 5 macam dan harus diketahui oleh perusahaan sebagai berikut :

1. Biaya Pembelian (Purchasing Cost) : biaya yang dikeluarkan unuk pembelian barang, biaya ini digolongkan ke dalam Variable Cost.

2. Biaya Pengadaan (Procurement Cost) : biaya yang dikeluarkan untuk pemesanan barang, mulai dari penentuan supplier sampai biaya preparation sebelum dilakukan penyimpanan.

3. Biaya Penyimpanan (Carrying Cost) : semua biaya yang timbul akibat penyimpanan.

Biaya ini meliputi : Suku bunga terhadap cost yang disimpan, kerusakan barang, tempat/sewa gudang, administrasi, asuransi, biaya kadaluarsa (obsolence).

4. Biaya kekurangan Persediaan (Shortage Cost) : biaya yang timbul akibat tidak tersedianya stock, jika ada permintaan tetapi tidak bisa supply karena tidak ada stock.

5. Biaya Sistemik (Systemik Cost) : biaya investasi untuk pengadaan suatu sistem pengadaan yang meliputi biaya perencanaan, pengadaan peralatan, dan pelatihan tenaga kerja.

\section{Metode-Metode Pengendalian Persediaan}

Untuk metode-metode pengendalian persediaan menurut pendapat Sofyan (2013:53) dibagi dalam 3 (tiga) metode, yaitu :

1. Metode pengendalian persediaan secara statistik (Statistical Inventory Control). Metode ini dilakukan untuk mengetahui beberapa kondisi persediaan seperti : menentukan jumlah ukuran pemesanan dinamis (Economic Order Quantity/EOQ), mengetahui kapan titik pemesanan kembali (Reorder Point) dilakukan dan mengetahui jumlah cadangan pengaman (safety stock) yang harus dimiliki perusahaan.

2. Metode perencanaan kebutuhan material (Material Requirement Planning). Sistem ini menggunakan pencatatan dari bill of material pada produk akhir kedalam proses produksi dan rencana pembelian dari berbagai komponen.

3. Metode persediaan tepat waktu (Just In Time). 
Sistem produksi tepat waktu atau dikenal dengan sistem produksi Just in Time (JIT) merupakan fiosofi yang memasukkan variasi konsep yang dihasilkan dari cara yang berbeda ketika melaksanakan bisnis pada kebanyakan organisasi.

\section{Fungsi Persediaan}

Fungsi utama persediaan yaitu sebagai penyangga, penghubung antar proses produksi dan distribusi untuk memperoleh efisiensi. Sebagai stabilisator harga terhadap fluktuasi permintaan. Persediaan bahan baku bertujuan untuk mengurangi ketidakpastian produksi akibat fluktuasi pasokan bahan baku, buffer stock dan komponen berguna untuk mengurangi ketidakpastian produksi akibat kerusakan mesin. Sedangkan persediaan produk jadi berguna untuk memenuhi fluktuasi permintaan yang tidak dapat dengan segera dipenuhi oleh produksi mengingat untuk produksi dibutuhkan bahan baku.

\section{Tujuan persediaan}

1. Menghilangkan resiko keterlambatan datangnya barang atau bahan-bahan yang dibutuhkan perusahaan.

2. Menghilangkan resiko kegagalan/kerusakan material yang dipesan sehingga harus dikembalikan.

3. Untuk menyimpan bahan-bahan yang dihasilkan secara musiman sehingga dapat digunakan bila bahan tersebut tidak ada di pasar.

4. Menjamin kelancaran proses produksi perusahaan.

5. Menjamin penggunaan mesin secara optimal.

6. Memberikan jaminan akan ketersediaan produk jadi kepada konsumen.

7. Dapat melaksanakan produksi sesuai keinginan tanpa menunggu adanya dampak/resiko penjualan.

\section{METODE PENELITIAN \\ Jenis/Disain Penelitian}

Jenis penelitian yang digunakan adalah penelitian kuantitatif deskriptif. Penelitian ini menurut Martono (2014 : 17) bertujuan untuk menggambarkan karakter suatu variable, kelompok atau gejala sosial yang terjadi di masyarakat. Adapun metode yang digunakan adalah motode $E O Q$. Metode $E O Q$ atau disebut metode Wilson pertama kali dicetuskan oleh Ford Haris pada tahun 1915, tetapi lebih dikenal dengan nama metode Wilson karena dikembangkan oleh Wilson pada tahun 1934.

\section{Variabel Penelitian.}

1. Variabel Economic Order Quantity.

Untuk mengetahui jumlah pembelian pesanan yang ekonomis. Dimensi dari Economic order quantity ini meliputi : kuantitas pemintaan, biaya pesan dan biaya simpan.

2. Variabel Persediaan Pengaman (Safety Stock).

Penentuan jumlah persediaan pengaman. Dimensi safety stock ini meliputi

kuantitas penjualan rata-rata.

3. Variabel Titik Pemesanan Kembali (Reorder Point)

Saat atau waktu tertentu perusahaan harus mengadakan pemesanan bahan dasar kembali, sehingga datangnya pesanan tersebut tepat dengan habisnya bahan 
dasar yang dibeli. Dimensi dari reorder point ini meliputi : kuantitas penjualan material dan waktu tunggu.

4. Variabel Total Biaya Persediaan Bahan Baku (TIC)

Perhitungan total biaya persediaan bahan baku minimal yang diperlukan perusahaan. Dimensi total biaya persediaan bahan baku ini meliputi waktu penyimpanan dan kuantitas pemesanan setiap kali pesan.

Metode Analisa Data

Menurut Simbar dkk (2014), EOQ, Safety Stock, Reorder Point dan TIC dapat ditentukan dengan cara sebagai berikut :

1. Economic Order Quantity (EOQ)
$E O Q=\sqrt{\frac{2 \cdot \mathrm{D} \cdot \mathrm{S}}{\mathrm{H}}}$
Dimana :

2. Safety Stock (Persediaan Pengaman)

$$
\begin{aligned}
& \mathrm{S}=\text { Biaya perpesanan } \\
& \mathrm{H}=\text { Biaya penyimpanan }
\end{aligned}
$$
Safety Stock $=\mathrm{Sd} \times \mathrm{Z} \quad$ dimana $: \mathrm{Sd}=$ Standard Deviasi $\mathrm{Z}=$ Faktor keamanan

$$
\mathrm{SD}=\sqrt{\frac{\sum(x-\bar{x})^{2}}{\mathbf{n}}} \quad \mathrm{X}=\text { Jumlah penjualan }
$$

$$
\begin{aligned}
\bar{X} & =\text { Rata-rata penjualan } \\
\mathrm{n} & =\text { Periode pemesanan }
\end{aligned}
$$

\section{Reorder Point (ROP)}

$$
\text { ROP }=\text { Safety } \quad \text { Stock }+\quad(\text { Lead } \text { time } \quad x \quad r)
$$

Dimana:

Lead time $=$ Waktu tunggu

Safety stock $=$ Persediaan pengaman $(\mathrm{kg})$

$\mathrm{Q}=$ Penjualan material rata-rata perbulan ( $\mathrm{kg} / \mathrm{bulan})$

\section{Total Inventory Cost (TIC)}

$$
\begin{array}{ll}
T I C=\sqrt{2 . \mathrm{D} \cdot \mathrm{S} \cdot \mathrm{H}} & \mathrm{D}=\text { Kuantitas penjualan } \\
& \mathrm{S}=\text { Biaya perpesanan } \\
& \mathrm{H}=\text { Biaya penyimpanan }
\end{array}
$$




\section{PEMBAHASAN}

\section{Pembelian dan Penjualan Material}

Penelitian diambil dari dua data penjualan material terbesar dari satu main customer dan dari satu supplier utama. Nama material yang diambil untuk penelitian dapat dilihat pada Tabel 1.

Tabel 1. Nama Material

\begin{tabular}{|l|c|c|}
\hline Supplier & $\mathrm{X}$ & $\mathrm{X}$ \\
\hline Customer & $\mathrm{A}$ & $\mathrm{A}$ \\
\hline Material & Tembaga XA1 & Tembaga XA2 \\
\hline
\end{tabular}

Data pembelian dan penjualan yang diperoleh dari perusahaan tersebut pada tahun 2015 seperti terlihat pada Tabel 2

Tabel 2. Pembelian dan Penjualan Material Customer A, PT. XYZ Tahun 2015

\begin{tabular}{|c|c|c|c|c|c|c|c|}
\hline \multirow[b]{2}{*}{ No. } & \multirow[b]{2}{*}{ Bulan } & \multicolumn{3}{|c|}{ Tembaga XA1 } & \multicolumn{3}{|c|}{ Tembaga XA2 } \\
\hline & & $\begin{array}{c}\text { Pembelian } \\
(\mathrm{Kg})\end{array}$ & $\begin{array}{c}\text { Penjualan } \\
(\mathrm{Kg})\end{array}$ & $+/-$ & $\begin{array}{c}\text { Pembelian } \\
(\mathrm{Kg})\end{array}$ & $\begin{array}{c}\text { Penjualan } \\
(\mathrm{Kg})\end{array}$ & $+/-$ \\
\hline 1 & Jan & & $1.327,50$ & $-1.327,50$ & & $1.418,80$ & $-1.418,80$ \\
\hline 2 & $\mathrm{Feb}$ & 815,5 & 363,5 & 452 & $1.291,60$ & $1.768,60$ & -477 \\
\hline 3 & Mar & & $1.544,50$ & $-1.544,50$ & $3.401,80$ & $1.903,60$ & $1.498,20$ \\
\hline 4 & Apr & $2.530,00$ & $1.669,00$ & 861 & $1.380,60$ & $1.069,20$ & 311,4 \\
\hline 5 & Mei & $1.916,50$ & $1.928,00$ & $-11,5$ & 657,6 & $1.297,00$ & $-639,4$ \\
\hline 6 & Juni & $2.682,50$ & $1.307,00$ & $1.375,50$ & $2.138,40$ & 423,6 & $1.714,80$ \\
\hline 7 & Juli & $2.913,00$ & $1.571,00$ & $1.342,00$ & & $1.012,40$ & $-1.012,40$ \\
\hline 8 & Agus & $1.929,00$ & $2.296,00$ & -367 & $1.069,60$ & $1.025,80$ & 43,8 \\
\hline 9 & Sept & $2.398,00$ & $1.761,00$ & 637 & & 220,4 & $-220,4$ \\
\hline 10 & Okt & 721 & $1.538,50$ & $-817,5$ & & 641,4 & $-641,4$ \\
\hline 11 & Nop & $3.722,50$ & $1.587,00$ & $2.135,50$ & & 450,8 & $-450,8$ \\
\hline 12 & Des & & $2.377,00$ & $-2.377,00$ & & 405 & -405 \\
\hline Jumlah & & $19.628,00$ & $19.270,00$ & 358 & $9.939,60$ & $11.636,60$ & $-1.697,00$ \\
\hline Frekuensi & & 9 & 12 & & 6 & 12 & \\
\hline Rata-rata & & $2.180,90$ & $1.605,80$ & & $1.656,60$ & 969,7 & \\
\hline
\end{tabular}


Berikut grafik pembelian material dari Customer A

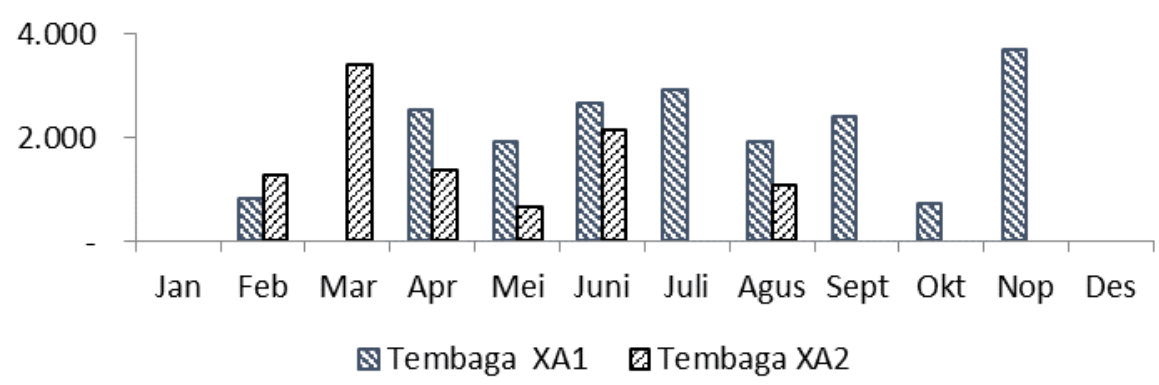

Gambar 1

Data Pembelian dari Customer A, PT. XYZ tahun 2015

\section{Biaya Pemesanan}

Biaya pemesanan material adalah biaya yang dikeluarkan sehubungan dengan pemesanan material, yaitu biaya pembebasan material dari bea cukai (customs clearance) termasuk ongkos transportasi. Lamanya pembebasan material berbanding lurus dengan biaya pemesanan. Ketersediaan original dokumen shipment dari supplier akan berdampak pada biaya pemesanan tadi. Karena tanpa original dokumen shipment, proses pembebasan material tidak dapat dilakukan, hal ini dikarenakan juga PT. XYZ tidak melakukan pembebasan material secara langsung tetapi menyewa jasa Forwarder. Selain itu ukuran container akan berdampak juga pada biaya pemesanan tadi. Biaya pemesanan tersebut adalah Supplier X : Rp. 633 / Kg

Biaya pemesanan ini dapat dilihat pada Tabel 3 dibawah ini.

Tabel 3. Biaya Pemesanan Material PT. XYZ tahun 2015

\begin{tabular}{|c|c|c|c|}
\hline \multirow[b]{2}{*}{ No. } & \multirow[b]{2}{*}{ Bulan } & \multicolumn{2}{|c|}{ Total Biaya Pesan } \\
\hline & & $\begin{array}{l}\text { XA1 } \\
\text { (Rp) } \\
\end{array}$ & $\begin{array}{l}\mathrm{XA2} \\
(\mathrm{Rp})\end{array}$ \\
\hline 1 & Jan & - & - \\
\hline 2 & Feb & 516.212 & 817.583 \\
\hline 3 & Mar & - & 2.153 .339 \\
\hline 4 & Apr & 1.601 .490 & 873.920 \\
\hline 5 & Mei & 1.213 .145 & 416.261 \\
\hline 6 & Juni & 1.698 .023 & 1.353 .607 \\
\hline 7 & Juli & 1.843 .929 & - \\
\hline 8 & Agus & 1.221 .057 & 677.057 \\
\hline 9 & Sept & 1.517 .934 & - \\
\hline 10 & Okt & 456.393 & - \\
\hline 11 & Nop & 2.356 .343 & - \\
\hline 12 & Des & - & - \\
\hline Jumlah & & 12.424 .526 & 6.291 .767 \\
\hline Frekuensi & & 9 & 6 \\
\hline Rata-rata & & 1.380 .503 & 1.048 .628 \\
\hline
\end{tabular}




\section{Biaya Penyimpanan}

Biaya penyimpanan material adalah biaya yang dikeluarkan berkaitan dengan penyimpanan material di warehouse. Biaya ini mencakup ongkos tenaga kerja, biaya asuransi, sewa warehouse, pemakaian listrik, pemakaian air, dan pemakaian telepone Untuk lebih jelasnya biaya penyimpanan ini dapat dilihat pada Tabel 4.

Tabel 4. Biaya Penyimpanan Material PT. XYZ tahun 2015

\begin{tabular}{|l|r|}
\hline \multicolumn{1}{|c|}{ Biaya } & Biaya/Kg (Rp) \\
\hline Ongkos Tenaga Kerja & 48 \\
\hline Biaya Asuransi & 222 \\
\hline Sewa warehouse & 52 \\
\hline Pemakaian Listrik & 46 \\
\hline Pemakaian Air & 1 \\
\hline Pemakaian Telepone & 5 \\
\hline Total & 374 \\
\hline
\end{tabular}

Analisis Hasil Penelitian

\section{Perhitungan Economic Order Quantity}

Pada penelitian ini penulis melakukan perhitungan EOQ. Adapun rumus yang digunakan adalah :

$$
\begin{aligned}
& E O Q=\sqrt{\frac{2 . \mathrm{D} \cdot \mathrm{S}}{\mathrm{H}}} \quad \text { Dimana } \quad S=\text { Biaya perpesanan } \\
& \mathrm{D}=\text { Jumlah penjualan }(\mathrm{kg}) \\
& \mathrm{H}=\text { Biaya penyimpanan }
\end{aligned}
$$

Dengan menggunakan rumus yang sama diperoleh untuk EOQ material XA1 adalah sebagai berikut :

$$
\begin{aligned}
& E O Q=\sqrt{\frac{2 S D}{H}} \\
= & \sqrt{\frac{2 \times 1380,503 \times 19270}{374}} \\
= & 11.927 \mathrm{~kg}
\end{aligned}
$$

Dengan cara yang sama diperoleh $E O Q$ untuk material XA2 seperti terlihat pada Tabel 5.

Tabel 5. Perhitungan EOQ, Material dari Customer A, PT. XYZ Tahun 2015

\begin{tabular}{|l|r|r|}
\hline \multicolumn{1}{|c|}{ Uraian } & Tembaga XA1 & Tembaga XA2 \\
\hline Kuantitas penjualan per periode $(\mathrm{Kg} /$ tahun) & 19.270 & 11.637 \\
\hline Biaya per pesanan $(\mathrm{Rp})$ & 1.380 .503 & 1.048 .628 \\
\hline Biaya penyimpanan per kg per periode $(\mathrm{Rp} / \mathrm{Kg} /$ tahun) & 374 & 374 \\
\hline EOQ & 11.927 & 8.078 \\
\hline
\end{tabular}




\section{Penentuan Persediaan Pengaman (Safety Stock)}

Safety stock atau persediaan pengaman adalah persediaan untuk mengantisipasi unsur ketidakpastian permintaan dan penyediaan. Apabila, persediaan pengaman tidak mampu mengantisipasi ketidakpastian tersebut, akan terjadi kekurangan persediaan (stockout). Penentuan jumlah persediaan pengaman dapat dilakukan dengan membandingkan penjualan material kemudian dicari berapa standar deviasinya. Setelah diketahui berapa besarnya standar deviasi maka akan ditetapkan besarnya analisis penyimpangan. Dalam analisis penyimpangan ini manajemen perusahaan menentukan seberapa jauh material yang masih dapat diterima.

Pada umumnya batas toleransi yang digunakan adalah $5 \%$ diatas perkiraan dan $5 \%$ dibawah perkiraan dengan nilai 1,65 (nilai $\mathrm{Z}$ didapatkan dari tabel distribusi normal), Tabel standar deviasi dapat dilihat pada Tabel 6. sampai dengan tabel 7. sebagai berikut :

Tabel 6. Deviasi Material Tembaga XA1, PT. XYZ tahun 2015

\begin{tabular}{|r|l|r|r|r|}
\hline No. & Bulan & $\begin{array}{r}\text { Penjualan }(\mathrm{kg}) \\
\mathrm{X}\end{array}$ & $\begin{array}{c}\text { Deviasi }(\mathrm{kg}) \\
(\mathrm{X}-\overline{\mathrm{X}})\end{array}$ & \multicolumn{1}{c|}{$\begin{array}{c}\text { Kuadrat } \\
(\mathrm{X}-\overline{\mathrm{X}})\end{array}$} \\
\hline 1 & Jan & $1.327,5$ & $-278,3$ & 77.469 \\
\hline 2 & Feb & 363,5 & $-1.242,3$ & 1.543 .392 \\
\hline 3 & Mar & $1.544,5$ & $-61,3$ & 3.762 \\
\hline 4 & Apr & $1.669,0$ & 63,2 & 3.990 \\
\hline 5 & Mei & $1.928,0$ & 322,2 & 103.791 \\
\hline 6 & Juni & $1.307,0$ & $-298,8$ & 89.301 \\
\hline 7 & Juli & $1.571,0$ & $-34,8$ & 1.213 \\
\hline 8 & Agus & $2.296,0$ & 690,2 & 476.330 \\
\hline 9 & Sept & $1.761,0$ & 155,2 & 24.077 \\
\hline 10 & Okt & $1.538,5$ & $-67,3$ & 4.534 \\
\hline 11 & Nop & $1.587,0$ & $-18,8$ & 355 \\
\hline 12 & Des & $2.377,0$ & 771,2 & 594.698 \\
\hline \multicolumn{2}{r|r|r|}{} & $19.270,0$ & 0,0 & 2.922 .913 \\
\hline Jumlah & & $1.605,8$ & & \\
\hline \multicolumn{2}{r|r}{ Rata-rata $(\bar{X})$} & & & \\
\hline
\end{tabular}

Berdasarkan rumus yang digunakan, perhitungan standar deviasi dilakukan sebagai berikut

$\mathrm{SD}=\sqrt{\frac{\sum(x-\bar{x})^{2}}{\mathrm{n}}}$

Dimana : $X=$ Jumlah penjualan material sesungguhnya perperiode ( $\mathrm{kg} / \mathrm{tahun})$ 


$$
\begin{aligned}
& \overline{\mathrm{X}}=\text { Rata-rata penjualan material }(\mathrm{kg}) \\
& \mathrm{N}=\text { Banyaknya periode pemesanan material }
\end{aligned}
$$

Sehingga dengan rumus tersebut diperoleh standard deviasi untuk material XA1 adalah:

$$
\begin{aligned}
\mathrm{SD} & =\sqrt{\frac{\sum(x-\bar{x})^{2}}{\mathrm{n}}} \\
& =\sqrt{\frac{2.992 .913}{12}} \\
& =493.5 \mathrm{~kg}
\end{aligned}
$$

Selanjutnya menentukan Persediaan Pengaman (Safety Stock) dengan rumus

$$
\text { Safety Stock }=\mathrm{Sd} \times \mathrm{Z}
$$

\begin{tabular}{|c|c|c|c|c|}
\hline No. & Bulan & $\begin{array}{c}\text { Penjualan }(\mathrm{kg}) \\
\mathrm{X} \\
\end{array}$ & $\begin{array}{l}\text { Deviasi }(\mathrm{kg}) \\
(\mathrm{X}-\overline{\mathrm{X}})\end{array}$ & $\begin{array}{c}\text { Kuadrat } \\
(\mathrm{X}-\overline{\mathrm{X}})\end{array}$ \\
\hline 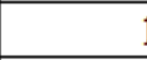 & Jan & $1.418,8$ & 449,1 & 201.676 \\
\hline 2 & Feb & $1.768,6$ & 798,9 & 638.215 \\
\hline & Mar & $1.903,6$ & 933,9 & 872.138 \\
\hline 2 & Apr & $1.069,2$ & 99,5 & 9.897 \\
\hline & Mei & $1.297,0$ & 327,3 & 107.114 \\
\hline s & Juni & 423,6 & 546,1 & 298.243 \\
\hline t & Juli & $1.012,4$ & 42,7 & 1.822 \\
\hline$\varepsilon$ & Agus & $1.025,8$ & 56,1 & 3.145 \\
\hline s & Sept & 220,4 & 749,3 & 561.475 \\
\hline 10 & Okt & 641,4 & 328,3 & 107.792 \\
\hline 1. & Nop & 450,8 & 518,9 & 269.275 \\
\hline 12 & Des & 405,0 & 564,7 & 318.905 \\
\hline Jumlah & & $11.636,6$ & - & 3.389 .697 \\
\hline \multicolumn{2}{|c|}{ Rata-rata $(\overline{\mathrm{X}})$} & 969,7 & & \\
\hline
\end{tabular}

Dimana :

$\mathrm{Sd}=$ Standard Deviasi

$\mathrm{Z}=$ Faktor keamanan dibentuk atas dasar kemampuan perusahaan.

$$
\begin{aligned}
\text { Safety Stock } & =493.5 \times 1.65 \\
& =814.3 \mathrm{~kg}
\end{aligned}
$$

Tabel 7. Deviasi Material Tembaga XA2, PT. XYZ tahun 2015

Hasil perhitungan secara lengkap Standar Deviasi dan Safety Stock material XA1 dan XA2 dapat dilihat pada Tabel 8. di bawah ini :

2015

Tabel 8. Standar Deviasi dan Safety Stock dari Customer A, PT. XYZ, Tahun

\begin{tabular}{|c|r|r|}
\hline Uraian & Tembaga XA1 & Tembaga XA2 \\
\hline Standar Deviasi & 493,5 & 531,5 \\
\hline Safety Stock $(\mathrm{Kg})$ & 814,3 & 876,9 \\
\hline
\end{tabular}


Dari analisa data di atas dapat disimpulkan bahwa makin besar standar deviasi yang terjadi semakin besar Safety Stock yang harus disiapkan.

\section{Penentuan Pemesanan Kembali (Reorder Point)}

Saat pemesanan kembali atau Reorder Point adalah saat dimana perusahaan harus melakukan pemesanan material kembali, sehingga penerimaan material yang dipesan dapat tepat waktu. Perhitungan ROP dilakukan dengan menggunakan rumus :

$$
R O P=\text { Safety Stock }+(\text { Lead time } x Q)
$$

Dimana:

ROP $\quad=$ Titik pemesanan kembali

Lead time $=$ Waktu tunggu

Safety stock $=$ Persediaan pengaman $(\mathrm{kg})$

$\mathrm{Q}=$ Penjualan material rata-rata perbulan ( $\mathrm{kg} / \mathrm{bulan})$

ROP untuk Customer A (Material XA1 dan XA2) :

$$
\begin{aligned}
& R O P(X A 1)=\text { Safety Stock }+(\text { Lead time } x Q) \\
& =814,3+(2 \times 1.605) \\
& =4.026 \mathrm{Kg} \\
& R O P(X A 2)=\text { Safety Stock }+(\text { Lead time } x Q) \\
& =876,9+(2 \times 969.7) \\
& =2.816,4 \mathrm{Kg}
\end{aligned}
$$

Tabel 9. Titik Pemesanan Kembali (Reorder Point) dari Customer A, PT. XYZ tahun 2015

\begin{tabular}{|l|r|r|}
\hline \multicolumn{1}{|c|}{ Uraian } & Tembaga XA1 & Tembaga XA2 \\
\hline Safety Stock & 814,3 & 876,9 \\
\hline Lead time & 2 & 2 \\
\hline Penjualan rata-rata & $1.605,8$ & 969,7 \\
\hline ROP & $4.026,0$ & $2.816,4$ \\
\hline
\end{tabular}

Dari tabel 9. dapat disimpulkan bahwa untuk material XA1 ROP dilakukan pada posisi total stock 2.5 penjualan rata-rata $(4.026 \mathrm{~kg} / 1.605 \mathrm{~kg})$, material XA2 ROP dilakukan pada saat posisi total stock 2,9 penjualan rata-rata $(2.816 \mathrm{~kg} / 969,7 \mathrm{~kg})$

Perhitungan Biaya Total Persediaan (Total Inventory Cost)

Untuk mengetahui total biaya persediaan bahan baku minimal yang diperlukan perusahaan dengan menggunakan perhitungan EOQ. Pada perhitungan biaya ini penulis melakukan perbandingan antara Biaya Total Persediaan metode EOQ dengan Kebijakan Perusahaan

Adapun perhitungan biaya total persediaan dengan metode $E O Q$ dilakukan dengan menggunakan rumus :

$$
\begin{aligned}
& T I C=\sqrt{2 . \mathrm{D} . \mathrm{S} . \mathrm{H}} \\
& \text { Dimana: } \\
& \mathrm{D}=\text { Kuantitas penjualan per periode (kg/tahun) } \\
& \mathrm{S}=\text { Biaya per pesanan (Rp/tahun) }
\end{aligned}
$$




$$
\mathrm{H}=\text { Biaya penyimpanan } \mathrm{kg}(\mathrm{Rp} / \mathrm{kg} / \mathrm{tahun})
$$

Sedangkan perhitungan berdasarkan kebijakan perusahaan dihitung dengan menggunakan rumus

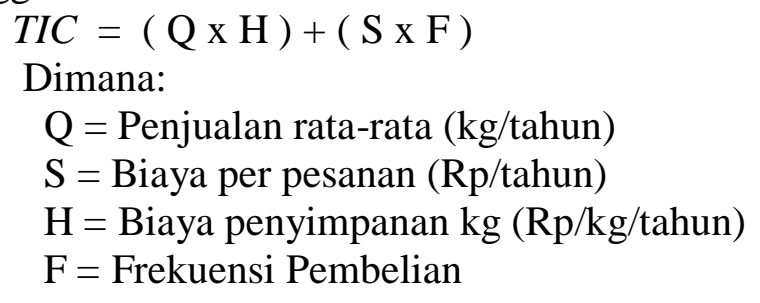

\section{Customer A}

Total biaya persediaan material XA1 berdasarkan $E O Q$ :

$$
\begin{aligned}
T I C & =\sqrt{2 . \mathrm{D} . \mathrm{S} . \mathrm{H}} \\
& =\sqrt{2 \times 19.270,0 \times 1.380 .503 \times 374} \\
& =\mathrm{Rp} .4 .460 .775
\end{aligned}
$$

Total biaya persediaan material XA1 berdasarkan Kebijakan Perusahaan :

$$
\begin{aligned}
T I C & =(\mathrm{Q} \times \mathrm{H})+(\mathrm{S} \times \mathrm{F}) \\
& =(1.605,8 \times 374)+(1.380 .503 \times 9) \\
& =\text { Rp. } 13.025 .108
\end{aligned}
$$

Dengan cara yang sama diperoleh hasil perhitungan material XA2

Tabel 10. Total Biaya Persediaan Material (TIC) Customer A, PT. XYZ tahun 2015

\begin{tabular}{|l|r|r|}
\hline \multicolumn{1}{|c|}{ Uraian } & Tembaga XA1 & Tembaga XA2 \\
\hline TIC Metode EOQ $(\mathrm{Kg})$ & 4.460 .775 & 3.021 .166 \\
\hline TIC kebijakan perusahaan $(\mathrm{Kg})$ & 13.025 .108 & 6.654 .441 \\
\hline
\end{tabular}

\section{Analisis Selisih Efisiensi Pemesanan Material yang Optimal dengan Pemesanaan Material yang dilakukan dengan Kebijakan PT. XYZ}

Dari hasil perhitungan yang dilakukan dapat dilihat perbandingan persediaan material antara kebijakan perusahaan dengan menggunakan metode $E O Q$, dilihat dari jumlah pembelian, frekuensi pembelian, total biaya persediaan, persediaan pengaman dan kapan seharusnya perusahaan memesan kembali material tersebut. Dapat dilihat pada table-tabel dibawah ini.

Tabel 11. Perbandingan persediaan material antara kebijakan perusahaan dengan menggunakan metode EOQ untuk Material Tembaga XA1 Customer A, PT. XYZ tahun 2015.

\begin{tabular}{|l|r|r|}
\hline \multicolumn{1}{|c|}{ Uraian } & Kebijakan Perusahaan & \multicolumn{1}{|c|}{ Metode EOQ } \\
\hline Kuantitas Pembelian $(\mathrm{Kg})$ & $2.180,9$ & $11.927,2$ \\
\hline Frekuensi Pembelian (kali) & 9,0 & 1,6 \\
\hline Persediaan Pengaman $(\mathrm{Kg})$ & - & 814,3 \\
\hline Titik Pemesanan Kembali $(\mathrm{Kg})$ & - & $4.026,0$ \\
\hline Total biaya persediaan $(\mathrm{Rp})$ & $13.025 .107,7$ & $4.460 .775,0$ \\
\hline
\end{tabular}


Tabel 12. Perbandingan persediaan material antara kebijakan perusahaan dengan menggunakan metode EOQ untuk Material Tembaga XA2 Customer A, PT. XYZ tahun 2015.

\begin{tabular}{|l|r|r|}
\hline \multicolumn{1}{|c|}{ Uraian } & Kebijakan Perusahaan & \multicolumn{1}{|c|}{ Metode EOQ } \\
\hline Kuantitas Pembelian $(\mathrm{Kg})$ & $1.656,6$ & $8.078,1$ \\
\hline Frekuensi Pembelian $(\mathrm{kali})$ & 6,0 & 1,4 \\
\hline Persediaan Pengaman $(\mathrm{Kg})$ & - & 876,9 \\
\hline Titik Pemesanan Kembali $(\mathrm{Kg})$ & - & $2.816,4$ \\
\hline Total biaya persediaan $(\mathrm{Rp})$ & $6.654 .441,0$ & $3.021 .165,7$ \\
\hline
\end{tabular}

Dari hasil di atas, penghematan total biaya persediaan sebesar 62\% (Rp. 12.197.608 ), dimana total biaya yang dihitung menurut kebijakan PT. XYZ sebesar Rp. 19.679.549 (total biaya persediaan dari Tabel 11 sampai Tabel 12), sedangkan yang dihitung menurut metode EOQ sebesar $\mathrm{Rp}$. 7.481 .941 (total biaya persediaan dari Tabel 11 sampai Tabel 12). Salah satu hal yang mempengaruhinya adalah karena perusahaan PT. XYZ sering melakukan order (frekuensi order relative sangat tinggi) sehingga akan terjadi pembengkakan pada biaya pesan.

\section{KESIMPULAN DAN SARAN}

Dari hasil penelitian dan pembahasan pada bab sebelumnya, dapat disimpulkan beberapa hal sebagai berikut :

1. Dengan menggunakan metode $E O Q$, kuantitas pemesanan material XA terhadap supplier X periode Januari 2015 - Desember 2015 akan mengalami peningkatan yang signifikan yaitu sebesar 488\% - 547\% (material XA) dibandingkan terhadap kebijakan perusahaan yang selama ini dijalankan.

2. Untuk mengatasi fluktuasi demand material, dan meminimasi biaya operasional pada Januari 2015 - Desember 2015 diperlukan adanya safety stock masingmasing : $51 \%-90 \%$ (material XA).

3. Biaya operasional PT. KMPI pada Januari 2015 - Desember 2015 akan lebih optimal jika memperhatikan variabel Reorder Point (ROP) dalam perhitungan order material. Besarnya ROP tersebut adalah 251\% - 290\% (material XA) dari rata-rata penjualan atau pada saat $2.5-2.9$ bulan stock.

4. Total biaya persediaan antara kebijakan PT. XYZ dengan metode $E O Q$ berbeda sangat signifikan untuk setiap material. Metode EOQ jauh lebih murah dari kebijakan PT. XYZ. Pada perioda Januari 2015 - December 2015 PT. XYZ dapat menghemat biaya dari setiap material sebesar 55\% - 66\% (material XA) atau rata-rata $60,5 \%$.

\section{DAFTAR PUSTAKA}

1. Arman Hakim Nasution, Yudha Prasetyawan. (2008). Perencanaan \& Pengendalian Produksi. edisi 1. Penerbit Graha Ilmu. Yogyakarta.

2. Diana Khairani Sofyan. (2013). Perencanaan \& Pengendalian Produksi edisi 1. Graha Ilmu. Yogyakarta

3. Mutiara Simbar, Theodora M. Katiandagho, Tommy F. Lolowang, Jenny Baroreh. (2014). "Analisis Pengendalian Bahan Baku Kayu Cempaka pada Industri Mebel Dengan Menggunakan Metode EOQ". Jurnal Ilmiah. Universitas Sam Ratulangi Manado.

4. Nanang Martono. (2014). Metode Penelitian Kuantitatif, Analisis Isi dan Analisis Data Sekunder. edisi revisi 2. RajaGrafika Persada. Jakarta.

5. Rosnani Ginting. (2012). Sistem Produksi edisi 1. Graha Ilmu, Yogyakarta 